\title{
An Analysis of Students' Language Learning Strategy and Lecturers' Language Teaching Strategy in Writing for Media Communication Class
}

\author{
Yozi Putri $^{1^{*}}$ and Sitti Fatimah ${ }^{2}$ \\ ${ }^{12}$ English Department, FBS Universitas Negeri Padang, Padang, Sumatra Barat 25131, Indonesia \\ "Corresponding author. Email: Jhy.putri@gmail.com
}

\begin{abstract}
Language Learning Strategies or also known as LLS and Lecturers' Language Teaching Strategies are two crucial points that have significant role in the use of language in communication. It is definitely need extra attempts to learn and teach English as a foreign language. This is becoming more interesting if the case was to learn and teach English in a vocational college. Consequently, both students and the lecturers need additional efforts because of the particular purpose of it. The purpose of vocational college is preparing the students with skills and ready to work in the field. This paper attempted to find interesting strategies that both the students and lecturers choose to achieve the goals of the vocational college, in a class of Writing for Media Communication in Politeknik Negeri Padang. The students were in second year in college and the lecturers who taught them. The data were gained in the beginning of Covid-19.
\end{abstract}

Keywords: Students' LLS, Lecturer's Language Teaching Strategy, Covid 19 Pandemic

\section{INTRODUCTION}

Polytechnic trains students to enhance their skills and ability. Sufficient practicing experiences and learning in the classroom are the attempts that polytechnic serves to help the students in gaining that purpose. One of several kind of polytechnic in west Sumatera is Politeknik Negeri Padang. PNP has several majors and one of them is English Department. The special thing of this major is serving a futuristic course called Writing for Media Communication course. This course aims to help students to enhance their ability to write a confident and truthful news which can publish in printed media, online media and broadcast media.

Students' language learning strategies play an important role for enhancing students' writing skill because it will help students to learn the language easier and more effective, also to regulate their learning which was respectively explain by Oxford [1] and Griffiths [2]. Besides, lecturer also find it challenging because teaching writing skill obstacle is students' limited chxoice of words as believes by Ghabool, Marriadas and Kashed [3]. Rozimela [4] in 2004 also believes that teaching writing skill is difficult because it is the most complex skill and lecturers' neglecting and often put aside. Therefore, a better understanding of appropriate teaching strategies will help to manage these obstacles.

However, in this Covid-19 Pandemic, almost all learning and teaching activity in Indonesia are changing dramatically. WHO or The World Health Organization classifies it as a new virus disease as SARS-CoV-2 or other known as Severe acute respiratory syndrome coronavirus-2 in disease terminology [5]. Relman explains this virus attacks human respiratory system and the transmission of this virus can spread from human to human [6]. Therefore, keeping the physical distance and health protocol is highly recommended to stop the virus spread. As a result, all university students are having classes in some online meeting applications with their lecturers. This issue also affects students and lecturers in the English Department of Politeknik Negeri Padang.

The data of students' tendencies in using strategies in this new condition of Covid-19 pandemic, this research used Oxford SILL Questionnaire [7]. Oxford promotes the instrument and luckily, researcher around the world used it in order to investigate students' language learning strategies, this instrument named as the Strategy Inventory for Language Learning or shortened as SILL. She creates this advance questionnaire into the 7.0 version, the latest. This questionnaire has been used in many parts of the world, the population and sample are learners of many different English native speaker students and non-native English students research. Ellis [8] believes that Oxford's SILL version 7.0 is widely approved because of the comprehensive classification of learning strategies that Oxford explains in her unique taxonomy. there was no distinction made between strategies that were used in 
language learning and in language use. Each choice of questionnaire covers different strategies. There are two classifications of the strategy; Direct Strategies and Indirect Strategies.

Oxford draws an explanation of both strategies' differences into an analogy of a theatre. Indirect strategies are considered as the director and direct strategies are considered as the actor. Director and actor are related one to another and work side by side. Director acts as internal guide and supports the actor. Director functions are focusing, organizing, guiding, checking, correcting, coaching, encouraging, cheering, and making sure the actor working cooperatively with other actors. It consists of metacognitive strategies (coordinating the actor play), affective strategies (regulating the actor emotions) and social strategies (encourage the actor to learn with other actors). Besides, Actor functions are memory strategies (remembering the line or dialogue and retrieving new dialogue), cognitive strategies (understand the dialogue and producing the dialogue or even improvised) and compensation strategies (using the dialogue although there are knowledge gaps about the meaning dialogue).

Besides, lecturers' language teaching strategies in this Covid-19 pandemic were almost using Internet and technology such as computer, laptop or Smartphone. This also encouraged students to use the same media in order to attend the class and let the learning activity run well. This new challenge triggered lecturers' to have appropriate strategies to face this new condition.

Thus, this study focused in analyzing the students' language learning strategies in Writing for Media Communication class and lecturers' Language teaching strategies in the same class. This study was limited into analyzing students' tendencies in choosing their LLS by using Oxford SILL Questionnaire [7] and analyzed lecturers' teaching strategies in the beginning of Covid-19 pandemic situation to help the other lecturers with same conditions to enrich their teaching strategies and tips.

\subsection{Related Work}

In recent years, the use of Oxford SILL is very popular in three categories. Mistar, Zuhairi, and Parlindungan [8] summarize the use of Oxford SILL by researchers around the world are general categories into three focuses; to reveal the use of strategies descriptively, to use it as a predictor of successful learning, and to find factors that may affect the use of learning. However, the focus of the studies nowadays was developing a specific language skill (speaking, listening, writing, and reading). Also some studies that used theories of learning strategies as theoretical bases.
Patmawati, Amri and Fatimah [9] study the level of speaking strategies of proficient students in English Education Department in academic year 2016/2017. On the other hand, Ardi reported learning style at senior high school in Padang [10]. The instrument they used to find out the strategy's usage level and the most used strategy is SILL by Oxford. They found the level of students' language strategies in medium usage with speaking strategies mean score point was 3.43 and the most used strategy is affective strategies. In addition, Lestari and Fatimah in 2020 administered SILL version 7.0 questionnaire by Oxford to 82 international student teachers in English Language Education Program of UNP [11]. The data showed most used strategy and least used strategy as Metacognitive strategy and Affective strategy. They also indicated international EFL student teachers as High Level because the mean score was 3.80 .

Sarjan and Madiana Analizing the teaching strategis that is used by the teacher in teaching reading comprehension in SMP 1 Wonomulyo [12]. This study found the teacher used some strategies; Scaffolding strategy (1), and QARs (Question Answer Relationship) (2). These strategies were believed make the student understand the reading text and gain more focus on the text. Therefore, teacher was able to help students in meaning developing that the text contained. This is more easily understand the contents of reading.

Due to this condition of Covid 19 pandemic, the activity of teaching and learning in almost all universities in Indonesia are online. Online teaching and learning might give advantage for lecturer and students. Nasution and Fattimah [13] mention that using a website called Pro Writing Aid is very useful for students and every type of writers. They also describe that this website is very attractive because students could verify their grammatical issue by their own and check other factors to enrich students writing products. This website could be one example for lecturer to enrich their teaching strategy in this pandemic situation.

\section{REVIEW OF RELATED LITERATURE 2.1. Language Learning Strategies}

Oxford [1] explains learning strategies is communication in a natural setting. Hence, learning strategies are drawn as some special techniques or behaviours that the learners used to acquire typical knowledge naturally. Further commonly used the technical term in the educational area is Language Learning Strategies (LLS). Generally, human processes information they got by using language to understand the typical idea and knowledge to help the development of human life. Consequently, Therefore, the language will facilitate human to help the idea delivered from one 
to another human, communicatively. Therefore, language also needs to be learned.

Oxford [1] states that LLS is an essential tool to develop students' communicative competence and other goals. The development of students' communicative competence requires interactions between students and students or between students and Lecturer by using a meaningful language. Good language learners are aware of it.

Oxford [1] draws an explanation of both strategies' differences into an analogy of a theatre. Indirect strategies are considered as the director and direct strategies are considered as the actor. Director and actor are related one to another and work side by side. Director is the internal guide to supports the actor. Director functions are focusing, organizing, guiding, checking, correcting, coaching, encouraging, cheering, and making sure the actor working cooperatively with other actors. It consists of meta-cognitive strategies (coordinating the actor play), affective strategies (regulating the actor emotions) and social strategies (encourage the actor to learn with other actors). Besides, Actor functions are; 1) memory strategies, for instance remembering the line or dialogue and retrieving new dialogue, 2) cognitive strategies (understand the dialogue and producing the dialogue or even improvised), and 3) compensation strategies (using the dialogue although there are knowledge gaps about the meaning dialogue).

Oxford also classified direct strategies into three kinds that each kind is also divided into some characteristics. The three strategies are memory strategies, cognitive strategies, and compensation strategies. Besides, Indirect strategies are divided into three kinds that each kind is also divided into some characteristics. The three strategies are meta-cognitive, affective strategies, and social strategies.

\subsection{Language Teaching Strategies}

Strategies in teaching are very simple and affected by lecturers' beliefs. This is because the way lecturers' beliefs affecting the method that the lecturer used in teaching. Also, strategies are simpler than approach and method. In addition, Richards and Roger [14] add designs after method and equal to techniques because they believe that designs include the syllabus model.

Teaching strategies could be categorized into five parts [15] that Hamruni describes into; 1) direct instruction strategy, 2) Indirect Instruction Strategy, 3) Interactive Teaching Strategy, 4) Experiential/Empirical Teaching Strategies, and 5) Independent Teaching Strategies. The direct teaching strategies is also known as teacher-centred-strategy. In contrast, the indirect teaching strategy is students-centred-strategy, teacher only acts as a facilitator. As for the interactive teaching strategy, it focuses on learners' interaction to another learner through discussion. In contrast, experiential teaching strategy emphasize the learning by students' experiences. Lastly, the independent teaching strategy purpose is developing learners' initiative in learning to learn individually.

\subsection{Oxford SILL Questionnaire}

Oxford [1] promotes a widely used instrument for investigating the language learning strategies that she named as Strategy Inventory for Language Learning or shortened as SILL. She creates this advance questionnaire into the 7.0 version, the latest. Studies about learners of many different English native speaker students and non-native English students around the world used this questionnaire. Surprisingly, wide numerous researchers around the world use Oxford's SILL version 7.0 to analysed students' LLS.

\subsection{Covid-19}

COVID-19 or known as Corona Virus Disease2019 is a type of virus that emerged in Wuhan, China in December 2019. There are more than hundreds countries have been contaminated by this virus. The World Health Organization or WHO [5] calls the new virus as Severe acute respiratory syndrome coronavirus2 or shortened as SARS-CoV-2. In addition, the disease is widely known as coronavirus disease 2019. PDPI (2020) mentions that the infection of this virus might cause mild, moderate, or severe symptoms, and the worst is caused death. Quoted from an official government website of Indonesia Peringatan COVID19 , the total infection cases up to 10 October 2020 is 6.561 people. This virus could spread by only have a close distance to other person and easily transfer from one to another by talking because it easily transfers through spittle. Due to these reasons, the Minister of Education and Culture Nadiem Makarim issued a commandment for handling the COVID-19 outbreak. He asked for every Department of Education at the provincial, district, and city levels, higher education institutions, higher education leaders, and principals through SE Number 3 of 202 to have an online meeting classes to prevent the face-to-face study activities. It concerned prevention of having physical contacts. Thus, students and lecturers having the learning and teaching process in houses. Students and lecturers can have a meeting, not physically face-to-face meeting, but a meeting through an online meeting application. 


\section{METHOD}

This is a descriptive quantitative study and used descriptive qualitative method. Cresswell [16] states that quantitative data, such as scores on instruments, gain specific numbers that can be analyzed statistically. He also believes that it provides useful information to describe trends about a large number of people. In this case, a descriptive quantitative method will be used to investigate the level of students' LLS average level in a class of Writing for Media Communication class. Also, the descriptive quantitative method will use to find out the most used LLS and the least used LLS by students.

There were 52 students as the respondents of Oxford SILL Questionnaire. The Questionnaire were consisted of 50 questions. The answers were divided into 5 different answers based on the scale of Likert; 1) Never, 2) Seldom, 3) Sometimes, 4) Usually, 5) Always. The respondents or the students had to choose one of 5 scale in each questions.

Meanwhile, the descriptive qualitative method used to investigate the strategy that the lecturers' used in the class that affected by Covid-19 pandemic. The lecturers were questioned with 20 questions related to teaching strategies during the beginning of Covid-19 Pandemic. There were 2 lecturers who interviewed. The data were rich in descriptions of steps, tips and solutions.

\section{DISCUSSION AND CONCLUSION 4.1 Students' Language Learning Strategies}

The final score of SILL by Oxford that used for students in the class of Writing for Media Communication level is explained in the table below.

\begin{tabular}{|l|l|l|l|}
\hline No & The Strategies & $\begin{array}{l}\text { Mean } \\
\text { Score }\end{array}$ & $\begin{array}{l}\text { Level of } \\
\text { Frequency } \\
\text { Used }\end{array}$ \\
\hline 1 & Cognitive Strategies & 4.01 & High Use \\
\hline 2 & Metacognitive Strategies & 3.95 & High Use \\
\hline 3 & Social Strategies & 3.90 & High Use \\
\hline 4 & Memory Strategies & 3.86 & High Use \\
\hline 5 & Affective Strategies & 3.54 & High Use \\
\hline 6 & Compensation Strategies & 3.53 & High Use \\
\hline
\end{tabular}

Table 2.1 LLS level used by students

The total score that became the Mean Score of this table is 3.80. Based on Oxford Categorization, the Mean score above 3.50 are considered as the High Level. The respondents using Cognitive strategies the most and Compensation strategies the least.

\subsection{Lecturers' Language Teaching Strategies}

The overall result of lecturers' explanation from interview indicated the differentiate of teaching strategies before and after Covi-19 Pandemic. Due to the new condition and no experiences to teach by distance in a class of full of practice with direct explanation and correction, lecturers tended to find unfamiliarity condition. Lecturers' tended to taught what they already prepared and taught the material by online meeting. The media that often used by the lecturers in teaching writing for Media Communication were; Zoom Meeting and Google Meet. Students tended to show less interest by turning of the camera and less interaction in the class than usual.

However, the real challenge of this Covid-19 Pandemic condition was the difficulty to let the students experience the field practice. Therefore, the lecturers resolved the condition by giving the students some solutions; 1) a fake condition of role-play, 2) students' online research, and 3) students Peer Reading. The fake condition let the students to pretend gathering the information outside their house. Such a mini role-play with their family. Then, in order to create truthful news products the students were asked to research some details about the news they interested to and rewrite the news with some evidence. Last, all news products that created by the students were being reviewed by the other students before become a final news products.

This study found that the students and lecturers who learned and taught in Writing for Media Communication class were having an awareness of the leaning strategies importance and believed that it was a part of their language learning process. The used of some strategies presenting these learners as High users for all categories of LLS. The students found as the High users for Cognitive strategies $(M=4.01)$ and it helped the learners' learning process in practicing, receiving and sending messages, analyzing and employing (summarizing). The students also found as the least used strategy of the Compensation strategy $(\mathrm{M}=3.53)$ and it showed the lack of guessing and applying images and sounds. Then, the study also showed that the lecturers were actively did their best to overcome the sudden pandemic in the very beginning of no face-to-face meeting without any experiences and strategies in a glance.

Based on discussion above, the researcher discovers students in this Covid-19 pandemic conditions tended to use Cognitive strategies because they practice by their own and lecturers tended to create impromptu strategies to let the learning activities run still. Hopefully, lecturers and students will find better strategies to face this further condition better in order to gain more than before. 


\section{REFERENCES}

[1] Oxford, R. L, Language Learning Strategies: What Every Lecturer Should Know, Boston: Heinly \& Heinly, 1990.

[2] Griffiths, Carol, Language Learning Strategies: Theory and Research, School of Foundations Studies AIS St Helens, Auckland, New Zealand, 2004.

[3] Ghabool, N. E, Marriadas, M. A. P., Kashed, H.S, Investigating Malaysian ESL students' writing: Problems on conventions, punctuation, and language use at the secondary school level, Journal Studies in Education, 2, 3, 2012.

[4] Rozimela, Yenni, The Value of Writing Skills in The Senior High Schools in Indonesia in Y. B. Cahyono (Ed.), The Tapestry of ELT and language in Indonesia, Malang: State University of Malang, 2004.

[5] WHO (World Health Organization), Corona Virus, Official website, 2020.

[6] Relman, Eliza, China Confirmed That The Deadly Wuhan Virus Sweeping The Country Can Spread from Human-to-human, Increasing The Risk of An Epidemic, Official Website Business Insider, 2020.

[7] Oxford, R. L, Language Learning Strategies: What Every Lecturer Should Know, Boston: Heinly \& Heinly, 1990.

[8] Mistar, J., Zuhairi, A., Parlindungan, F, Strategies of learning English writing skill by Indonesian senior high school students, Arab World English Journal, 5(1), 290-303. 2014.

[9] Patmawati, Dewi., Zul Amri, and Sitti Fatimah, An Analysis of Speaking Learning Strategies Used by Proficient Learner of English Language And Literature Department in Universitas Negeri Padang, E Journal UNP. Padang, 2018.

[10] Ardi, H. Profil gaya belajar siswa SMA Negeri 7 Padang. Komposisi: Jurnal Pendidikan Bahasa, Sastra dan Seni 7(2). 2006.

[11] Lestari, Trinanda Mahdiyah and Sitti Fatimah, An Analysis Of Language Learning Strategies Used By Efl Student Teachers At English Language Education Program In Universitas Negeri Padang, E Journal UNP, Padang, 2020.

[12] Sarjan, Nurmadia and Mardiana, An Analysis On The English Teachers Strategies In Teaching Reading Comprehension Smp 1 Of Wonomulyo, Jurnal UIN Alauddin, 2017.

[13] Nasution, Aisyah and Sitti Fatimah, The Use of Pro Writing Aid Web in Editing Students Writing. E Journal UNP, Padang, 2018.

[14] Richards, J. and Rodgers T, Approaches and Methods in Language Teaching, New York: Cambridge University Press, 2001, http://dx.doi.org/10.1017/CBO9780511667305.021.
[15] Hamruni. Strategi Pembelajaran, Insan Madani, 2012.

[16] Cresswell, John W, Research Design: Qualitative, Quantitative, Mixed-Method Approaches, SAGE Publications, 2013. 